\title{
Enhanced shoot investment makes invasive plants exhibit growth advantages in high nitrogen conditions
}

\author{
X. A. Liu' , Y. Peng ${ }^{1}$, J. J. Li ${ }^{1}$ and P. H. Peng ${ }^{1 *}$ \\ ${ }^{1}$ Ecological Resources and Landscape Research Institute, Chengdu University of Technology, \\ Chengdu 610059, CHN, China \\ *e-mail: peihaop@163.com
}

Received: September 21, 2016 - Accepted: August 8, 2017 - Distributed: February 28, 2019

(With 3 figures)

\begin{abstract}
Resource amendments commonly promote plant invasions, raising concerns over the potential consequences of nitrogen (N) deposition; however, it is unclear whether invaders will benefit from $\mathrm{N}$ deposition more than natives. Growth is among the most fundamental inherent traits of plants and thus good invaders may have superior growth advantages in response to resource amendments. We compared the growth and allocation between invasive and native plants in different $\mathrm{N}$ regimes including controls (ambient $\mathrm{N}$ concentrations). We found that invasive plants always grew much larger than native plants in varying $\mathrm{N}$ conditions, regardless of growth- or phylogeny-based analyses, and that the former allocated more biomass to shoots than the latter. Although $\mathrm{N}$ addition enhanced the growth of invasive plants, this enhancement did not increase with increasing $\mathrm{N}$ addition. Across invasive and native species, changes in shoot biomass allocation were positively correlated with changes in whole-plant biomass; and the slope of this relationship was greater in invasive plants than native plants. These findings suggest that enhanced shoot investment makes invasive plants retain a growth advantage in high $\mathrm{N}$ conditions relative to natives, and also highlight that future $\mathrm{N}$ deposition may increase the risks of plant invasions.
\end{abstract}

Keywords: allocation strategies, invasive plants, native plants, nitrogen amendments, resource allocation.

\section{O investimento de tiro aumentado faz plantas invasivas exposição de vantagens de crescimento em altas condições de nitrógeno}

\begin{abstract}
Resumo
As alterações de recursos geralmente promovem invasões de plantas, suscitando preocupações quanto às conseqüências potenciais da deposição de nitrogênio $(\mathrm{N})$; No entanto, não está claro se os invasores se beneficiarão da deposição de $\mathrm{N}$ mais do que com os nativos. O crescimento é um dos traços inerentes mais fundamentais das plantas e, portanto, os bons invasores podem ter vantagens de crescimento superiores em resposta a alterações de recursos. Comparamos o crescimento e a alocação entre plantas invasivas e nativas em diferentes regimes de $\mathrm{N}$, incluindo controles (concentrações ambientais de N). Descobrimos que as plantas invasivas sempre cresceram muito mais do que as plantas nativas em diferentes condições de $\mathrm{N}$, independentemente das análises baseadas em crescimento ou filogenia, e que o primeiro atribuiu mais biomassa aos rebentos do que o segundo. Embora $\mathrm{N}$ aumentou o crescimento de plantas invasivas, esse aumento não aumentou com o aumento da adição de N. Através das espécies invasivas e nativas, as mudanças na alocação da biomassa do extrato foram correlacionadas positivamente com as mudanças na biomassa da planta inteira; e a inclinação desse relacionamento foi maior em plantas invasivas do que plantas nativas. Essas descobertas sugerem que o aumento do investimento em lançamentos faz com que as plantas invasivas mantenham uma vantagem de crescimento em altas condições de $\mathrm{N}$ em relação aos nativos, e também destacar que a futura deposição de $\mathrm{N}$ pode aumentar os riscos de invasões de plantas.
\end{abstract}

Palavras-chave: estratégias de alocação, plantas invasivas, plantas nativas, emendas de nitrogênio, alocação de recursos.

\section{Introduction}

What makes exotic plants become successful invaders is a core question in invasion ecology (van Kleunen et al., 2010a). For example, there are dozens of hypotheses that might explain the success of invasive species (Catford et al.,
2009; Jeschke, 2014). This situation suggests at least two implications: this question is highly attractive so that increasing attention has been paid to address it (Early et al., 2016), and it is extremely complex so that no single-factor hypothesis 
can provide unified explanations. Essentially, plant invasion is the process in which exotic plant species displace native species, particularly dominant natives, and subsequently dominate invaded communities. In this context comparing the performance of invasive and native species in the same conditions is crucial to understanding the mechanisms by which invasive species outperform native species (Funk and Vitousek, 2007; van Kleunen et al., 2010a, b; Leffler et al., 2014; Kuebbing et al., 2015).

Two of the leading hypotheses, fluctuating resources (Davis et al., 2000) and resource release (Blumenthal, 2005), highlight the importance of resource amendments in driving plant invasions. Nitrogen $(\mathrm{N})$ is an essential plant nutrient and many terrestrial plants face conditions of low $\mathrm{N}$ availability (LeBauer and Treseder, 2008; Bobbink et al., 2010; Liang et al., 2016). With high nitrate reductase activity, a key physiological mechanism in converting $\mathrm{N}$ into plant growth, good invaders tend to benefit more from high $\mathrm{N}$ apply than natives (He et al., 2012). Accordingly, soil $\mathrm{N}$ amendments are a recognized driver of invasion success (Davis et al., 2000; Daehler, 2003; Funk and Vitousek, 2007; Bradley et al., 2010). Increasing studies show that most regions on the Earth will have increased inputs of atmospheric N deposition (Galloway et al., 2004; Liu et al., 2013; Lu and Tian, 2014). Higher rates of $\mathrm{N}$ deposition are increasing soil $\mathrm{N}$ availability so that they may alleviate $\mathrm{N}$ limitation in some parts of the world (Galloway et al., 2004; Bradley et al., 2010; Yan et al., 2016), but high concentrations or amendments of $\mathrm{N}$ can also promote dominance and invasion by exotic plants (Daehler, 2003; Bradley et al., 2010). The consequences of $\mathrm{N}$ deposition for plant invasions depend primarily on three aspects: the duration, the total amount, and the $\mathrm{N}$ form of the inputs; the intrinsic sensitivity of the plant species present; and abiotic conditions in the ecosystem (Bobbink et al., 2010).

The effects of $\mathrm{N}$ deposition on plants involve at least two mechanisms: acidification and eutrophication (Bobbink et al., 2010; Stevens et al., 2010). This dual effect allows $\mathrm{N}$ deposition to become a hotly debated topic. For example, $\mathrm{N}$ deposition is a recognized threat to biodiversity due to acidification in some cases (Clark and Tilman, 2008; Chen et al., 2013), and also can enhance primary production due to eutrophication in some occasions (Stevens et al., 2015, and references therein; Yan et al., 2016). What happens to invasive and native species when $\mathrm{N}$ deposition occurs? Extrapolations from previous research suggest that $\mathrm{N}$ deposition could simultaneously influence invasive and native species directly and indirectly. For example, $\mathrm{N}$ deposition might yield contrasting effects on invasive and native species due to their differences in sensitivities and ecological strategies (Daehler, 2003; Gilliam, 2006; Bradley et al., 2010; Eskelinen and Harrison, 2014). Additionally, $\mathrm{N}$ deposition can alter soil conditions (Bi et al., 2012; Rowe et al., 2012; Chen et al., 2013), thereby impacting invasive and native species. As a result, it is possible that soil $\mathrm{N}$ amendment could affect the growth strategies of invasive and native species at the same time.
Concerns about how invasive plants will interact with $\mathrm{N}$ deposition have been articulated (Bradley et al., 2010). Until recently, there were limited studies comparing invasive and native responses to predicted $\mathrm{N}$ deposition (He et al., 2012; Jones and Power, 2015). Here, we provide data on how $\mathrm{N}$ addition influences the growth of invasive and native species. Accordingly, we selected five invasive plant species and six native plant species which belong to the same families (i.e. Asteraceae and Poaceae) and commonly occupy similar habitats, and compared their growth and allocation in three different $\mathrm{N}$ regimes. We focused on the following questions: (1) do invasive plants grow better than native plants in varying $\mathrm{N}$ conditions? (2) If so, what makes invasive plants exhibit a growth advantage compared to natives?

\section{Material and Methods}

To contrast the performance of invasive plants and native plants, we selected five invasive species (i.e., Bidens pilosa, Bromus tectorum, Centaurea stoebe, Eupatorium adenophorum, and Solidago canadensis), which are successful invaders, and six native species (i.e., Achillea millefolium, Bromus japonica, Eupatorium chinense, Helianthus annuus, Poa pratensis, and Vulpia octoflora), which are dominant/common natives in the invaded regions. Specifically, B. tectorum and $C$. stoebe have seriously invaded grasslands and abandoned agricultural lands in North America, and $A$. millefolium, $H$. annuus, $P$. pratensis, and $V$. octoflora are native to North America; B. pilosa, E. adenophorum, and $S$. canadensis have seriously invaded grasslands and abandoned agricultural lands in China, and B. japonica, E. chinense, and $P$. pratensis are native to China. The seeds of all the focal species were collected from invaded regions.

We conducted greenhouse experiments. Plants from all invasive and native species were grown alone. Since our goal was to contrast the performance of invasive and native species at different $\mathrm{N}$ deposition regimes we repeated this entire design three times, once for control (ambient $\mathrm{N}$ concentrations), again for low deposition rates $\left(1 \mathrm{~g} \mathrm{~N} \mathrm{~m}^{-2} \mathrm{yr}^{-1}\right)$, and a third time for high deposition rates ( $4 \mathrm{~g} \mathrm{~N} \mathrm{~m}^{-2} \mathrm{yr}^{-1}$ ). The replicates for each species under each $\mathrm{N}$ treatment were 10 so that the total replication for all $\mathrm{N}$ treatments and species was 330 . Based on the predictions for future $\mathrm{N}$ deposition rates (Galloway et al., 2004), we used 1 and $4 \mathrm{~g} \mathrm{~N} \mathrm{~m}^{-2} \mathrm{yr}^{-1}$ as low and high deposition rates.

In a search of the literature, 55\% of the previous studies we found used ammonium nitrate $\left(\mathrm{NH}_{4} \mathrm{NO}_{3}\right)$ for simulating $\mathrm{N}$ deposition. Thus we simulated $\mathrm{N}$ deposition by adding $\mathrm{NH}_{4} \mathrm{NO}_{3}$. $\mathrm{N}$ was applied as a solution of $\mathrm{NH}_{4} \mathrm{NO}_{3}$ in deionized water. All plants were grown from seed and grown in $500 \mathrm{~cm}^{3}$ pots filled with local soil. Abiotic conditions were controlled so that growing conditions were identical for all plants. The experiment lasted from June to September so that the pot size could not limit the root growth of seedlings (i.e., $500 \mathrm{~cm}^{3}$ pots were enough for experimental seedlings). During the course of the experiment, greenhouse temperatures were maintained $15-30^{\circ} \mathrm{C}$; natural light in the greenhouse was supplemented by metal halide 
bulbs, and total photosynthetically active radiation during the day remained above $1200 \mathrm{mmol} \mathrm{m}^{-2} \mathrm{~s}^{-1}$; all plants were watered every 2-3 days depending on the local weather. At the end of the experiment, all plants were harvested, washed, and separated into shoots and roots. Plants were dried at $60^{\circ} \mathrm{C}$ for $48 \mathrm{~h}$ and weighed. The total biomass per plant was equal to the sum of shoot biomass and root biomass. Shoot biomass allocation was calculated as the ratio of shoot biomass to the total biomass.

To quantify the effects of $\mathrm{N}$ deposition rates on the growth and allocation of invasive and native plants, the relative change in growth and allocation was calculated as follows: $\left(\mathrm{T}_{\mathrm{n}}-\mathrm{T}_{\mathrm{c}}\right) / \mathrm{T}_{\mathrm{c}} \times 100 \%$, where $\mathrm{T}_{\mathrm{n}}$ is the total biomass or shoot biomass allocation of plants subjected to $\mathrm{N}$ addition (low and high $\mathrm{N}$ deposition rates) and $\mathrm{T}_{\mathrm{c}}$ is the counterparts of plants subjected to no $\mathrm{N}$ addition. This relative change allowed us to highlight $\mathrm{N}$ treatment benefits and to conduct cross-species comparisons.

We used two approaches to analyze our growth data. First, we exploited general linear models to test the impacts of $\mathrm{N}$ addition on plant growth. Specifically, we used a nested analysis of variance (ANOVA), where both $\mathrm{N}$ addition (i.e., 1 versus $4 \mathrm{~g} \mathrm{~N} \mathrm{~m}^{-2} \mathrm{yr}^{-1}$ ) and species origin (invasive versus native plant species) were treated as fixed factors, and species identity nested within species origin was treated as a random factor, to test their influences on plant growth. Additionally, we used a nested ANOVA, where species origin was treated as a fixed factor and species identity nested within species origin was treated as a random factor, to test the effect of species origin on plant growth at a given $\mathrm{N}$ condition. The statistical analyses were performed with SPSS (19.0).

Second, we used a phylogenetic analysis to test whether there were species biases which species selection may involve in multiple species comparisons (Felsenstein, 1985; Davies et al., 2012). Specifically, we calculated phylogenetically independent contrasts (PICs) of shoot biomass, root biomass, and the total biomass. We created plant phylogenies using 'Phylomatic' software online (http://phylodiversity.net/phylomatic/). To resolve polytomies, randomization was performed with the 'multi2di' function in the 'picante' package (Purvis and Garland, 1993; Davies et al., 2012). The PICs were calculated using the 'pic' function in the 'picante' package (R 3.0.1, R Development Core Team).

For invasive and native plant species, a regression analysis was used to quantify the relationships between changes in the whole-plant biomass and changes in shoot biomass allocation. We performed the regression analysis using the "MASS" package (R 3.0.1, R Development Core Team) to compare the slopes and intercepts of invasive species and native species.

\section{Results}

Overall there were significant differences in shoot biomass, root biomass, and the total biomass between invasive plants and native plants (Table 1: effect of species origin, all $P<0.001)$. Specifically, in terms of the total biomass, invasive plants $(1.10 \pm 0.07 \mathrm{~g})$ grew much larger than native plants $(0.61 \pm 0.03 \mathrm{~g})$ when no $\mathrm{N}$ was added
Table 1. Analyses of variance of shoot biomass, root biomass, and the total biomass as affected by nitrogen $(\mathrm{N})$ addition, species origin (SO), and species identity (SI). Values of $P<0.05$ are in bold.

\begin{tabular}{cccccccc}
\hline \multirow{2}{*}{ Factor } & \multicolumn{2}{c}{$\begin{array}{c}\text { Shoot } \\
\text { biomass }\end{array}$} & \multicolumn{2}{c}{$\begin{array}{c}\text { Root } \\
\text { biomass }\end{array}$} & \multicolumn{2}{c}{$\begin{array}{c}\text { Total } \\
\text { biomass }\end{array}$} \\
\cline { 2 - 6 } & $\boldsymbol{F}$ & $\boldsymbol{P}$ & $\boldsymbol{F}$ & $\boldsymbol{P}$ & $\boldsymbol{F}$ & $\boldsymbol{P}$ \\
\hline $\mathrm{N}$ & $\mathbf{6 4 . 1 5}$ & $<\mathbf{0 . 0 0 1}$ & $\mathbf{5 0 . 3 4}$ & $<\mathbf{0 . 0 0 1}$ & $\mathbf{7 9 . 8 5}$ & $<\mathbf{0 . 0 0 1}$ \\
$\mathrm{SO}$ & $\mathbf{1 5 9 . 1}$ & $<\mathbf{0 . 0 0 1}$ & $\mathbf{2 9 . 7 7}$ & $<\mathbf{0 . 0 0 1}$ & $\mathbf{1 3 6 . 3}$ & $<\mathbf{0 . 0 0 1}$ \\
$\mathrm{SI}$ & $\mathbf{4 2 . 0 3}$ & $<\mathbf{0 . 0 0 1}$ & $\mathbf{2 0 . 7 9}$ & $<\mathbf{0 . 0 0 1}$ & $\mathbf{3 8 . 9 4}$ & $<\mathbf{0 . 0 0 1}$ \\
$\mathrm{N} \times \mathrm{SO}$ & $\mathbf{1 0 . 5 6}$ & $<\mathbf{0 . 0 0 1}$ & 0.052 & 0.949 & $\mathbf{5 . 1 5 9}$ & $\mathbf{0 . 0 0 6}$ \\
\hline
\end{tabular}

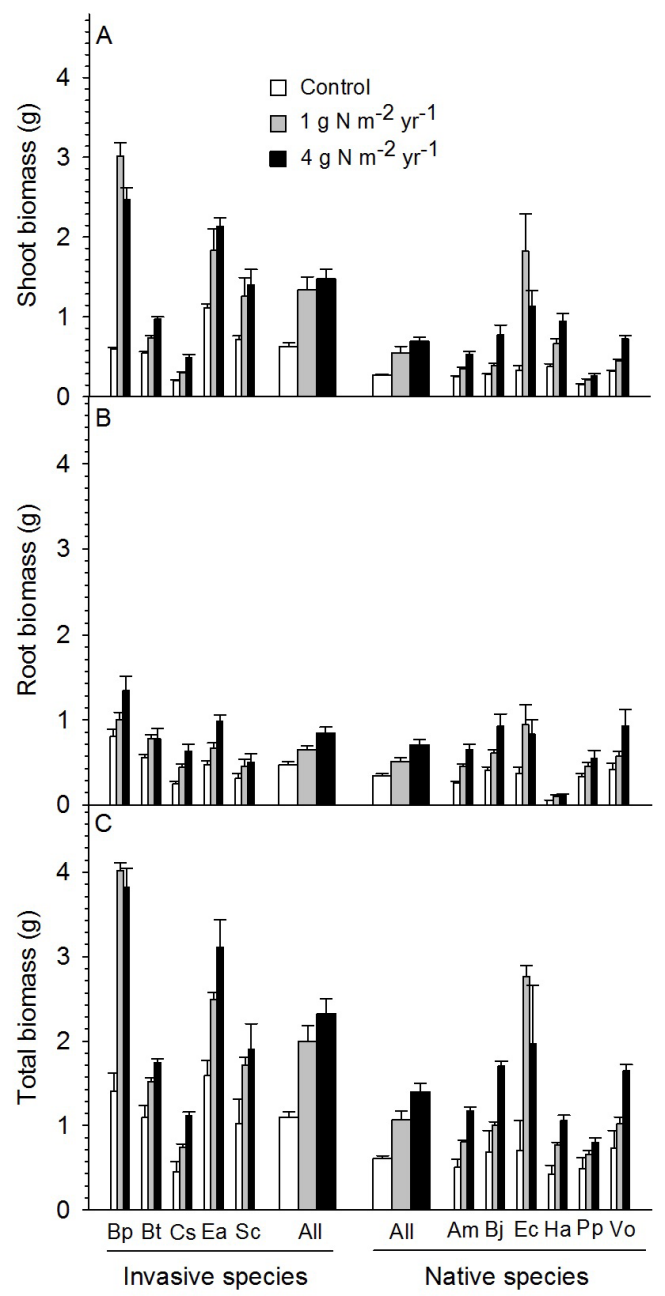

Figure 1. Shoot biomass (A), root biomass (B), and the total biomass $(\mathrm{C})$ as affected by nitrogen $(\mathrm{N})$ addition, species origin, and species identity. Narrow bars are the mean $+1 \mathrm{SE}$ for each species, and wide bars (center of figure) are the mean+1 SEforallspeciesbelongingtoinvasiveornativespecies. Bp:Bidens pilosa; Bt: Bromus tectorum; Cs: Centaurea stoebe; Ea: Eupatorium adenophorum; Sc: Solidago canadensis; Am: Achillea millefolium; Bj: Bromus japonica; Ec: Eupatorium chinense; Ha: Helianthus annuus; Pp: Poa pratensis; Vo: Vulpia octoflora. 


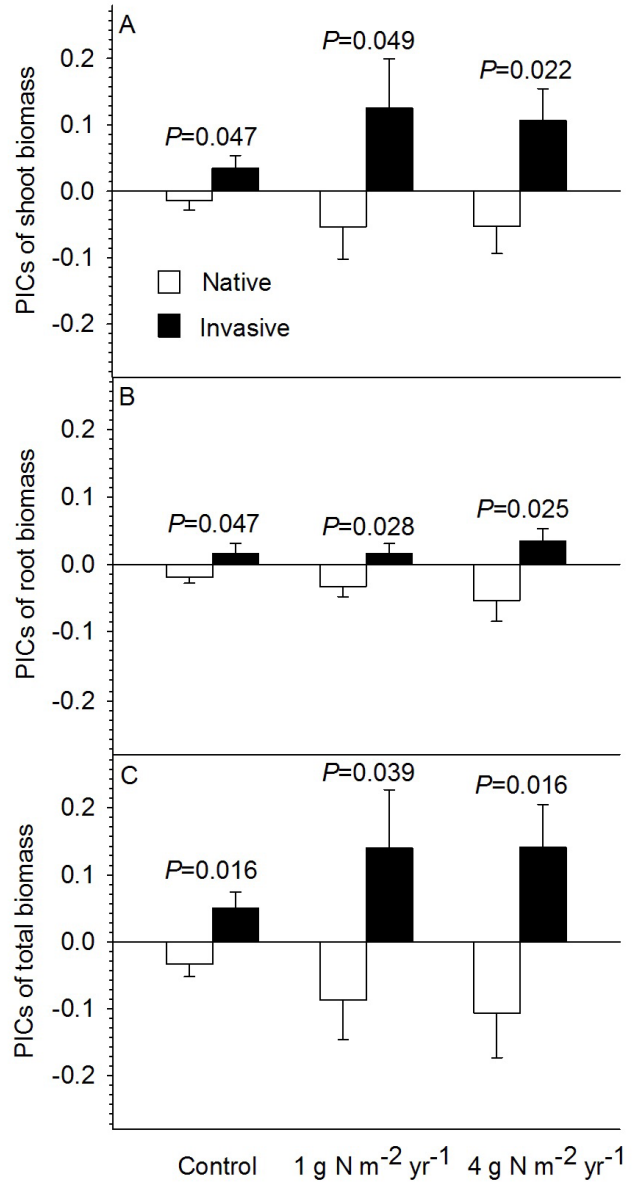

Figure 2. PICs of shoot biomass (A), PICs of root biomass (B), and PICs of the total biomass (C) as affected by nitrogen addition and species origin (i.e., native and invasive plant species).

(Figure 1C: $F=128.1, P<0.001)$; invasive plants $(1.99 \pm 0.19 \mathrm{~g})$ grew much bigger than native plants $(1.06 \pm 0.11 \mathrm{~g})$ when low $\mathrm{N}$ was added (Figure 1C: $F=63.20, P<0.001$ ); invasive plants $(2.32 \pm 0.18 \mathrm{~g})$ grew much larger than native plants $(1.40 \pm 0.10 \mathrm{~g})$ when high $\mathrm{N}$ was added (Figure 1C: $F=55.92, P<0.001$ ). The total biomass of invasive plants $(1.79 \pm 0.10 \mathrm{~g})$ was much greater than that of native species $(1.02 \pm 0.06 \mathrm{~g})(F=46.20, P<0.001)$ when all three $\mathrm{N}$ treatments were pooled together. Additionally, invasive plants allocated more biomass to shoots than native plants $(60.3 \pm 1.5 \%$ versus $48 \pm 1.4 \% ; F=64.06, P<0.001)$.

For shoot biomass and the total biomass, there were strong interactions between $\mathrm{N}$ addition and species origin (Table 1: interactive effect of $\mathrm{N}$ addition and species origin). In contrast, this interaction was not observed for root biomass (Table 1: non-significant effect of $\mathrm{N}$ addition by species origin). $\mathrm{N}$ addition dramatically increased the mean shoot biomass, root biomass, and total biomass of invasive and native plant species (Table 1: effect of

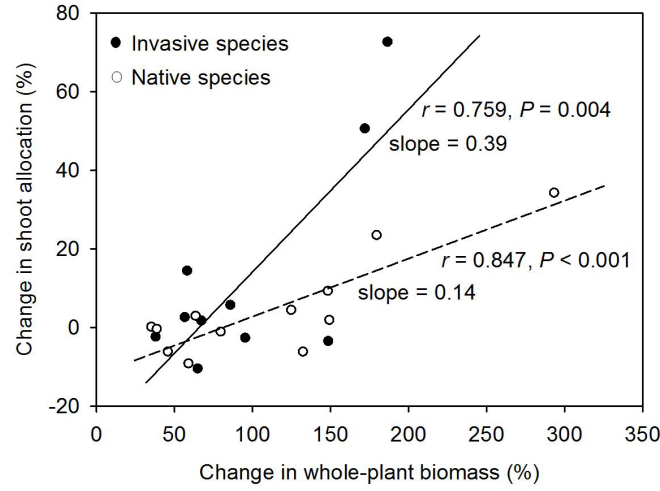

Figure 3. Relationships between changes in whole-plant biomass and changes in shoot biomass allocation. Each symbol represents the values for each species grown in low- and high-N conditions.

$\mathrm{N}$ addition; Figure 1A, B, C). There were significant variations in shoot biomass, root biomass, and the total biomass among invasive or native species (Table 1: effect of species identity; Figure 1A, B, C).

The phylogenetic analysis showed that invasive plants also always grew bigger than native plants in three N conditions (Figure 2). Specifically, PICs of shoot biomass were greater in invasive plants than native plants (Figure 2A: all $P<0.05$ ); PICs of root biomass were greater in invasive plants than native plants (Figure 2B: all $P<0.05$ ); PICs of the total biomass were greater in invasive plants than native plants (Figure $2 \mathrm{C}$ : all $P<0.05$ ). Thus biomassand phylogeny-based results were highly similar.

Changes in shoot allocation were positively correlated with changes in the whole-plant biomass (Figure 3: $r=0.759$ and $P=0.004$ for invasive species; and $r=0.847$ and $P<0.001$ for native species). The slope of this relationship was greater in invasive species $(0.39)$ than in native species $(0.14)(P<0.05)$, and the intercepts were similar between invasive and native species $(P>0.05)$. In other words, invasive species allocated more biomass to shoots than native species when increases in the total biomass were equal due to soil $\mathrm{N}$ amendment.

\section{Discussion}

Cross-species comparisons (also known as multiple species comparisons) are common in ecology. However, note that this approach should be used carefully because species selection may involve a species bias. To solve this potential problem phylogenetic analysis has long been suggested (Felsenstein, 1985; Davies et al., 2012). Accordingly, we used two different approaches (i.e., classical growth analysis and phylogenetic analysis) to analyze our growth data. Fortunately, these two approaches generated similar results. In other words, these species used in our study did not contain significant species biases. 
Based on comparisons of five dominant invasives and six dominant natives, we found that invasive plants and native plants differed in growth, that is, the former grew larger and allocated more biomass to shoots than the latter. These findings support the classical paradigm that functional differences between invasive and native species potentially constitute a determinant responsible for plant invasion (Daehler, 2003; Leicht-Young et al., 2007; van Kleunen et al., 2010b; Leffler et al., 2014; Kuebbing et al., 2015), and suggest that fast growth and high shoot allocation act in concert to allow invasive plants to perform better. Our findings also indicate that the roots of invasive plants may have a higher capacity to take up soil resources than those of native plants due to disproportional growth and allocation. The differences in performance between invasive and native species are closely linked to their inherent traits (Daehler, 2003; Leffler et al., 2014; Kuebbing et al., 2015). N addition enhanced the growth of invasive and native species. This effect has been generally supported by studies that manipulate resources (Daehler, 2003) and can be linked to the fact that $\mathrm{N}$ addition increases soil nutrient availability, thereby favoring biomass accumulation through increasing leaf nutrient contents and net photosynthesis (He et al., 2010; Ren et al., 2011).

Biomass allocation represents one of the most fundamental pathways of plants to cope with different environments and thus is incorporated into ecological strategies (Grime, 2001). Our finding that invasive plants allocated more biomass to shoots than native plants implies that the dominance of invaders seems to be linked to their higher aboveground biomass allocation. There are two possibilities for this finding. First, the aboveground competition between invasive and native species may play a more important role in shifting species dominance than the belowground competition. Second, as suggested above, roots of invasive plants may be more efficient in absorbing soil resources than those of native plants. Contrary to our currently thought, $\mathrm{N}$ addition decreased the root allocation of invasive species relative to native species. Accordingly, $\mathrm{N}$ amendment greatly allowed invasive species to allocate more biomass to their shoots compared to native species. This difference can be attributed to species origin (Meiners, 2007) and thus endows invaders with competitive advantages.

The most novel contribution of this study is that we provide a mechanistic explanation why soil $\mathrm{N}$ amendments increase the growth advantage of invasive plants (i.e., amplifying effects of soil $\mathrm{N}$ amendments). Specifically, $\mathrm{N}$ addition dramatically increased the whole-plant biomass of invasive species, enhancing their growth advantage. Second, the slope of the relationship between changing shoot allocation and changing whole-plant biomass was greater in invasive species than in native species. In other words, when $\mathrm{N}$ amendments increased the same magnitude of biomass, a higher fraction of the increased investment was allocated to the aboveground parts in invasive species than in native species. Invasive plants commonly allocate a higher fraction of leaf $\mathrm{N}$ to photosynthesis and have a higher photosynthesis potential than native plants (Feng et al., 2007; Feng, 2008). When the growth and biomass allocation of invasive plants are considered together, $\mathrm{N}$ deposition may exhibit amplifying effects on the growth advantage of invasive plant species. Additionally, shoots and roots responded differentially to $\mathrm{N}$ addition, suggesting that $\mathrm{N}$ deposition may have asymmetric effects on the aboveground and belowground parts of invasive plant species.

Atmospheric $\mathrm{N}$ deposition represents one of the most large-scale and wide-reaching perturbations to terrestrial ecosystems (Galloway et al., 2004) so that it may influence plant invasions (Daehler, 2003; Bradley et al., 2010). Since the size of invasive plants commonly is bigger than that of native plants (Leicht-Young et al., 2007; van Kleunen et al., 2010b), high $\mathrm{N}$ conditions enlarge this growth advantage and thus increase competitive advantages. According to the predicted studies by Galloway et al. (2004) and long-term monitoring data by $\mathrm{Lu}$ and Tian (2014), $\mathrm{N}$ deposition may reach up to $5 \mathrm{~g} \mathrm{~N} \mathrm{~m}^{-2} \mathrm{yr}^{-1}$ or even higher by 2050. Consequently, our findings suggest that future $\mathrm{N}$ deposition can enhance the risks of invasive species through increasing the growth and competitive ability of invasive plant species, in support of the previous concerns over the consequences of $\mathrm{N}$ deposition for plant invasions (Bradley et al., 2010).

In summary, simulated $\mathrm{N}$ deposition had differential effects on the growth and biomass allocation of invasive and native species, both of which are important components of ecological strategies. Invasive plants are commonly characterized as growing larger and allocating more biomass to shoots. $\mathrm{N}$ addition not only enhanced plant growth but also ramped up shoot allocation, thereby amplifying growth and competitive advantages. Accordingly, future atmospheric $\mathrm{N}$ deposition is more likely to favor invasive plants. Our findings also highlight the importance of comparing growth strategies between invasive and native species in elucidating invasion mechanisms.

\section{References}

BI, J., ZHANG, N.L., LIANG, Y., YANG, H.J. and MA, K.P., 2012. Interactive effects of water and nitrogen addition on soil microbial communities in a semiarid steppe. Journal of Plant Ecology, vol. 5, no. 3, pp. 320-329. http://dx.doi.org/10.1093/ jpe/rtr046.

BLUMENTHAL, D., 2005. Interrelated causes of plant invasion. Science, vol.310, no. 5746, pp. 243-244. http://dx.doi.org/10.1126/ science.1114851. PMid:16224008.

BOBBINK, R., HICKS, K., GALLOWAY, J., SPRANGER, T., ALKEMADE, R., ASHMORE, M., BUSTAMANTE, M., CINDERBY, S., DAVIDSON, E., DENTENER, F., EMMETT, B., ERISMAN, J.-W., FENN, M., GILLIAM, F., NORDIN, A., PARDO, L. and DE VRIES, W., 2010. Global assessment of nitrogen deposition effects on terrestrial plant diversity: a synthesis. Ecological Applications, vol. 20, no. 1, pp. 30-59. http://dx.doi. org/10.1890/08-1140.1. PMid:20349829. 
BRADLEY, B.A., BLUMENTHAL, D.M., WILCOVE, D.S. and ZISKA, L.H., 2010. Predicting plant invasions in an era of global change. Trends in Ecology \& Evolution, vol. 25, no. 5, pp. 310-318. http://dx.doi.org/10.1016/j.tree.2009.12.003. PMid:20097441.

CATFORD, J.A., JANSSON, R. and NILSSON, C., 2009. Reducing redundancy in invasion ecology by integrating hypotheses into a single theoretical framework. Diversity \& Distributions, vol. 15, no. 1, pp. 22-40. http://dx.doi.org/10.1111/j.1472-4642.2008.00521.x.

CHEN, D., LAN, Z., BAI, X., GRACE, J.B. and BAI, Y., 2013. Evidence that acidification-induced declines in plant diversity and productivity are mediated by changes in below-ground communities and soil properties in a semi-arid steppe. Journal of Ecology, vol. 101, no. 5, pp. 1322-1334. http://dx.doi. org/10.1111/1365-2745.12119.

CLARK, C.M. and TILMAN, D., 2008. Loss of plant species after chronic low-level nitrogen deposition to prairie grasslands. Nature, vol. 451, no. 7179, pp. 712-715. http://dx.doi.org/10.1038/ nature06503. PMid: 18256670 .

DAEHLER, C.C., 2003. Performance comparisons of co-occurring native and alien invasive plants: Implications for conservation and restoration. Annual Review of Ecology Evolution and Systematics, vol. 34, no. 1, pp. 183-211. http://dx.doi.org/10.1146/annurev. ecolsys.34.011802.132403.

DAVIES, T.J., KRAFT, N.J., SALAMIN, N. and WOLKOVICH, E.M., 2012. Incompletely resolved phylogenetic trees inflate estimates of phylogenetic conservatism. Ecology, vol. 93, no. 2, pp. 242-247. http://dx.doi.org/10.1890/11-1360.1. PMid:22624305.

DAVIS, M.A., GRIME, J.P. and THOMPSON, K., 2000. Fluctuating resources in plant communities: a general theory of invasibility. Journal of Ecology, vol. 88, no. 3, pp. 528-534. http://dx.doi. org/10.1046/j.1365-2745.2000.00473.x.

EARLY, R., BRADLEY, B.A., DUKES, J.S., LAWLER, J.J., OLDEN, J.D., BLUMENTHAL, D.M., GONZALEZ, P., GROSHOLZ, E.D., IBANEZ, I., MILLER, L.P., SORTE, C.J.B. and TATEM, A.J., 2016. Global threats from invasive alien species in the twenty-first century and national response capacities. Nature Communications, vol. 10, pp. 1-9. http://dx.doi.org/1038/ncomms 12485.

ESKELINEN, A. and HARRISON, S., 2014. Exotic plant invasions under enhanced rainfall are constrained by soil nutrients and competition. Ecology, vol. 95, no. 3, pp. 682-692. http://dx.doi. org/10.1890/13-0288.1. PMid:24804452.

FELSENSTEIN, J., 1985. Phylogenies and the comparative method. American Naturalist, vol. 125, no. 1, pp. 1-15. http:// dx.doi.org/10.1086/284325.

FENG, Y.L., 2008. Photosynthesis, nitrogen allocation and specific leaf area in invasive Eupatorium adenophorum and native Eupatorium japonicum grown at different irradiances. Physiologia Plantarum, vol. 133, no. 2, pp. 318-326. http:// dx.doi.org/10.1111/j.1399-3054.2008.01072.x. PMid:18312498.

FENG, Y.L., AUGE, H. and EBELING, S.K., 2007. Invasive Buddleja davidii allocates more nitrogen to its photosynthetic machinery than five native woody species. Oecologia, vol. 153, no. 3, pp. 501-510. http://dx.doi.org/10.1007/s00442-007-0759-2. PMid:17534664

FUNK, J.L. and VITOUSEK, P.M., 2007. Resource-use efficiency and plant invasion in low-resource systems. Nature, vol. 446, no. 7139, pp. 1079-1081. http://dx.doi.org/10.1038/nature05719. PMid:17460672.
GALLOWAY, J.N., DENTENER, F.J., CAPONE, D.G., BOYER, E.W., HOWARTH, R.W., SEITZINGER, S.P., ASNER, G.P., CLEVELAND, C.C., GREEN, P.A., HOLLAND, E.A., KARL, D.M., MICHAELS, A.F., PORTER, J.H., TOWNSEND, A.R. and VÖRÖSMARTY, C.J., 2004. Nitrogen cycles: past, present and future. Biogeochemistry, vol. 70, pp. 153-226. http://dx.doi. org/10.1007/s10533-004-0370-0.

GILLIAM, F.S., 2006. Response of the herbaceous layer of forest ecosystems to excess nitrogen deposition. Journal of Ecology, vol. 94, no. 6, pp. 1176-1191. http://dx.doi.org/10.1111/j.13652745.2006.01155.x.

GRIME, J.P. 2001. Plant strategies, vegetation processes, and ecosystem properties, $2^{\text {nd }}$ ed. Chichester, UK: John Wiley \& Sons Ltd, pp. 417

HE, W.M., MONTESINOS, D., THELEN, G.C. and CALLAWAY, R.M., 2012. Growth and competitive effects of Centaurea stoebe populations in response to simulated nitrogen deposition. PLoS One, vol. 7, no. 4, pp. e36257. http://dx.doi.org/10.1371/journal. pone.0036257. PMid:22563451.

HE, W.M., YU, F.H. and ZHANG, L.L., 2010. Physiological integration impacts nutrient use and stoichiometry in three clonal plants under heterogeneous habitats. Ecological Research, vol. 25, no. 5, pp. 967-972. http://dx.doi.org/10.1007/s11284-010-0724-0.

JESCHKE, J.M., 2014. General hypothesis in invasion ecology. Diversity \& Distributions, vol. 20, no. 11, pp. 1229-1234. http:// dx.doi.org/10.1111/ddi.12258.

JONES, A.G. and POWER, S.A., 2015. Functional relationships with $\mathrm{N}$ deposition differ according to stand maturity in Callunadominated heathland. Ambio, vol. 44, no. 2, pp. 131-141. http:// dx.doi.org/10.1007/s13280-014-0529-4. PMid:24845194.

KUEBBING, S.E., CLASSEN, A.T., SANDERS, N.J. and SIMBERLOFF, D., 2015. Above- and below-ground effects of plant diversity depend on specie origin: an experimental test with multiple invaders. The New Phytologist, vol. 208, no. 3, pp. 727-735. http://dx.doi.org/10.1111/nph.13488. PMid:26053089.

LEBAUER, D.S. and TRESEDER, K.K., 2008. Nitrogen limitation of net primary productivity in terrestrial ecosystems is globally distributed. Ecology, vol. 89, no. 2, pp. 371-379. http://dx.doi. org/10.1890/06-2057.1. PMid:18409427.

LEFFLER, A.J., JAMES, J.J., MONACO, T.A. and SHELEY, R.L., 2014. A new perspective on trait differences between native invasive exotic plants. Ecology, vol. 95, no. 2, pp. 298-305. http:// dx.doi.org/10.1890/13-0102.1. PMid:24669724.

LEICHT-YOUNG, S.A., SILANDER JUNIOR, J.A. and LATIMER, A.M., 2007. Comparative performance of invasive and native Celastrus species across environmental gradients. Oecologia, vol. 154 , no. 2, pp. 273-282. http://dx.doi.org/10.1007/s00442007-0839-3. PMid:17724616

LIANG, T., TONG, Y.A., LIU, X.J., XU, W., LUO, X.S. and CHRISTIE, P., 2016. High nitrogen deposition in an agricultural ecosystem of Shaanxi, China. Environmental Science and Pollution Research International, vol. 23, no. 13, pp. 13210-13221. http:// dx.doi.org/10.1007/s11356-016-6374-1. PMid:27023807.

LIU, X., ZHANG, Y., HAN, W., TANG, A., SHEN, J., CUI, Z., VITOUSEK, P., ERISMAN, J.W., GOULDING, K., CHRISTIE, P., FANGMEIER, A. and ZHANG, F., 2013. Enhanced nitrogen deposition over China. Nature, vol. 494, no. 7438, pp. 459-462. http://dx.doi.org/10.1038/nature11917. PMid:23426264. 
LU, C. and TIAN, H., 2014. Half-century nitrogen deposition increases across China: a gridded time-series data set for regional environmental assessments. Atmospheric Environment, vol. 97, pp. 68-74. http://dx.doi.org/10.1016/j.atmosenv.2014.07.061

MEINERS, S.J., 2007. Native and exotic species exhibit similar population dynamics during succession. Ecology, vol. 88, no. 5, pp. 1098-1104. http://dx.doi.org/10.1890/06-1505. PMid:17536395.

PURVIS, A. and GARLAND, T., 1993. Polytomies in comparative analyses of continuous characters. Systematic Biology, vol. 42, no. 4, pp. 569-575. http://dx.doi.org/10.1093/sysbio/42.4.569.

REN, H., XU, Z., HUANG, J., CLARK, C., CHEN, S. and HAN, X., 2011. Nitrogen and water addition reduce leaf longevity of steppe species. Annals of Botany, vol. 107, no. 1, pp. 145-155. http://dx.doi.org/10.1093/aob/mcq219. PMid:21084404.

ROWE, E.C., EMMETT, B.A., FROGBROOK, Z.L., ROBINSON, D.A. and HUGHES, S., 2012. Nitrogen deposition and climate effects on soil nitrogen availability: influences of habitat type and soil characteristics. The Science of the Total Environment, vol. 434, pp. 62-70. http://dx.doi.org/10.1016/j.scitotenv.2011.12.027. PMid:22245213.

STEVENS, C.J., LIND, E.M., HAUTIER, Y., HARPOLE, W.S., BORER, E.T., HOBBIE, S., SEABLOOM, E.W., LADWIG, L., BAKKER, J.D., CHU, C., COLLINS, S., DAVIES, K.F., FIRN, J., HILLEBRAND, H., PIERRE, K.J.L., MACDOUGALL, A., MELBOURNE, B., MCCULLEY, R.L., MORGAN, J., ORROCK,
J.L., PROBER, S.M., RISCH, A.C., SCHUETZ, M. and WRAGG, P.D., 2015. Anthropogenic nitrogen deposition predicts local grassland primary production worldwide. Ecology, vol. 96, no. 6, pp. 1459-1465. http://dx.doi.org/10.1890/14-1902.1.

STEVENS, C.J., THOMPSON, K., GRIME, J.P., LONG, C.J. and GOWING, D.J.G., 2010. Contribution of acidification and eutrophication to declines in species richness of calcifuge grasslands along a gradient of atmospheric nitrogen deposition. Functional Ecology, vol. 24, no. 2, pp. 478-484. http://dx.doi. org/10.1111/j.1365-2435.2009.01663.x.

VAN KLEUNEN, M., DAWSON, W., SCHLAEPFER, D., JESCHKE, J.M. and FISCHER, M., 2010a. Are invaders different? A conceptual framework of comparative approaches for assessing determinants of invasiveness. Ecology Letters, vol. 13, no. 8, pp. 947-958. PMid:20576028.

VAN KLEUNEN, M., WEBER, E. and FISCHER, M., 2010b. A meta-analysis of trait differences between invasive and non-invasive plant species. Ecology Letters, vol. 13, no. 2, pp. 235-245. http:// dx.doi.org/10.1111/j.1461-0248.2009.01418.x. PMid:20002494.

YAN, G.Y., XING, Y.J., XU, L.J., WANG, J.Y., MENG, W., WANG, Q.G., YU, J.H., ZHANG, Z., WANG, Z.D., JIANG, S.L., LIU, B.Q. and HAN, S.J., 2016. Nitrogen deposition may enhance soil carbon storage via change of soil respiration dynamic during a spring freeze-thaw cycle period. Scientific Reports, vol. 6, pp. 29134. http://dx.doi.org/10.1038/srep29134. 